\title{
香川県仲多度郡満濃町炭所西地区における 溜池及び沢水の鉄起源の解明 \\ ORIGIN OF IRON IN RIVER AND POND WATER AROUND SUMISYONISHI DISTRICT, MANNO TOWN, KAGAWA PREFECTURE
}

\author{
室賀英治 1 ・井伊博行 2 . 中島敦司 ${ }^{3} \cdot$ 谷口正伸 4 \\ Eiji MUROGA, Hiroyuki II, Atushi NAKASHIMA and Masanobu TANIGUCHI

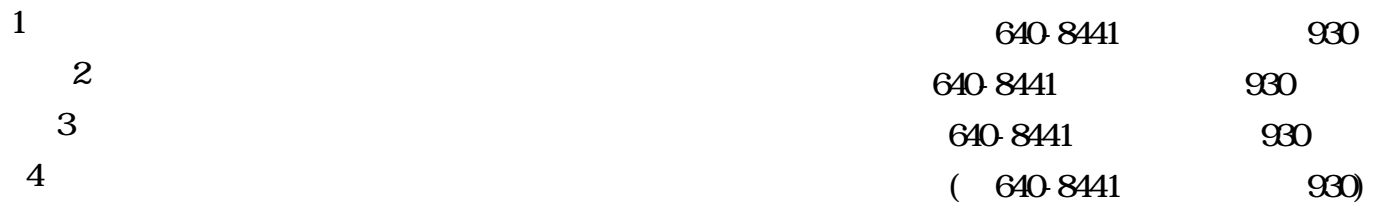

Fe concentrations in the brook and pond water around the Sumisyonisi district in Kagawa prefecture were extremely high and some of the brook water reached over $50 \mathrm{mg} / \mathrm{L}$. Fe concentrations of soil and plants were also analyzed to determine the Fe origin. Fe concentrations of brook and pond water were high along the upper stream and decreased down the stream. In particular, Fe concentrations of the upper stream water at the marsh surrounded by the forest were high. Reductive and low $\mathrm{pH}$ condition caused by decomposition of organic compounds such as leaves was thought to increase Fe solubility. Fe concentrations of tree leaves around the forest were very low although Fe concentrations of leaves of water plant were high. As Fe in soil and weathered rock were easily soluble in reduction and low $\mathrm{pH}$ condition, the origin of $\mathrm{Fe}$ in water was thought to be soil and weathered rock.

Key Words: Fe, Fe concentration of leaves, marsh, reductive condition, forest

\section{1 .はじめに}

香川県の国立讃岐まんのう公園内には自然生態園と いう施設があり，生態園内には逆樣池という溜池がある . 逆樣池の環境を保全するため, 毎年冬に浚渫作業などが 行われており, 逆樣池富栄養化しないように, 及び生 態系を保つために維持・管理をしている．このような環 境保全の結果, 逆樣池の水生植物は貧栄養の生態系を維 持している.

しかし, 逆樣池では水中の栄養塩の基となる落葉落 枝か㴟く堆積している . また , 逆樣池の水は赤褐色であ る.このような環境にもかかわらず, 逆樣池での水生植 物の優先種は, ジュンサイ , フトヒルムシロ , イヌタヌ キモ，ヒツジグサなどの貧栄養を好む水生植物である . 本研究の以前にも逆樣池での水質力貧栄養に維持される メカニズムの研究がなされており, 逆樣池では, 腐植土 か堆積している底部で酸素が㳄乏し, 酸化還元電位が 低くなるため，この環境力植物にとって必須の栄養分で
あるアンモニウムイオンや硝酸イオンを窒素ガスに変え ることがわかってきた (脱公) ${ }^{1)}$. また逆樣池流域のほ とんどの地域では鉄濃度か高く, 鉄は 3 価から 2 価へ還 元され, 水中に鉄 (II) イオンが溶出することがわかっ ている ${ }^{1)}$.さらに還元的な環境下では, 硫酸イオンを硫 化水素ガスに変え大気中に放出することで, アミノ酸の 成分として生物の活性に必要な硫黄が水中から取り除か れる ${ }^{2)}$. しかし , 鉄の起源や鉄の溶解の詳細なメカニズ 么は明らかにされておらず, 逆樣池の水の鉄濃度か高い 原因を解明する必要がある .

本研究では逆樣池周辺の鉄濃度が高い原因, 及ひ鉄 の起源について考察するため, 逆樣池周辺の沢水及び溜 池の調査を行い, さらに鉄の起源と考えられる土畩およ び岩石についての解析を行った .

\section{2 . 調査概要及び研究方法}

調査対象地は, 香川県仲多度郡にある国営讃岐まん 


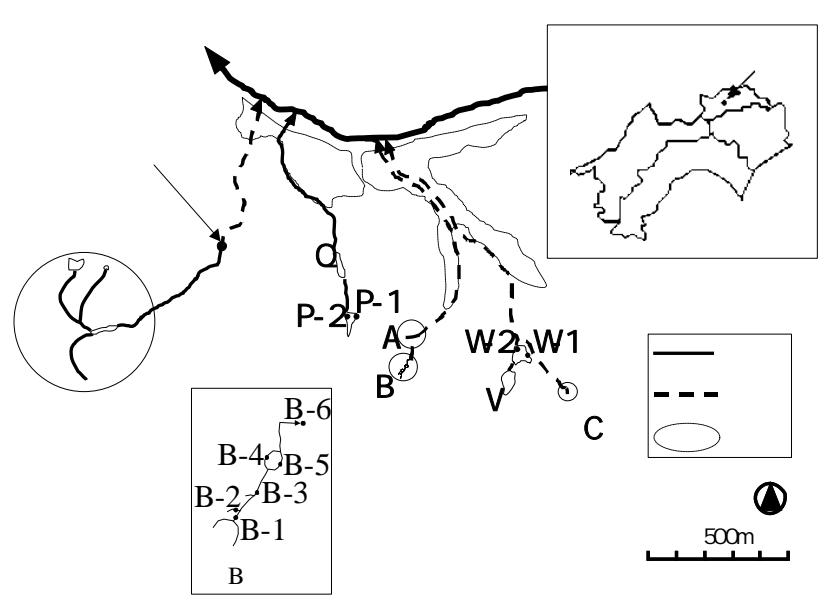

図-1 炭所西地区の調査地点

のう公園内の逆樣池と光の流域 , 及び公園外の東部にあ る炭所西地区である . 逆樣池の面積は約 $900 \mathrm{~m}^{2}$ である . 調査日は2004年6月3〜4日，2004月7月29日，2004年8月 10〜11日，2004年10月28～29日，2005年6月1〜2日， 2005年7月8〜9日，2005年8月22〜23日の計7回の現地調 査を行なった . 図-1に炭所西地区の調査地点を，また 図-2に逆樣池の調査地点を示す . 逆樣池には北の谷, 南 の谷, 東の谷から水が流入するが, 本研究では鉄濃度が 高い東の谷に着目する . 逆樣池流域の水の流れとしては , まず湧水が小池に流入し，杉とシ名植物の生い茂った東 の谷を流れ，逆樣池入流入する . 逆樣池からは用水路を 通り, 土器川入流れ込む。

また逆樣池の水質と比較するため，流域外の炭所西 の溜池P，Q，V，Wに着目した . 溜池P，Qは，まわり は林で囲まれ，水生植物は溜池Pの奥にガマが僅かに生 える程度である . 溜池Pから流れた水は林内を流れ , 溜 池Qへ流入し, 弚の後は水田群へ流出する . 溜池 $\mathrm{P} は 上$ 流部P-1と下流部P-2に分けて考察し, P-1は池の上流部， P-2は流出する部分て採水した . 溜池Vからの水は溜池W へ流れ, 兴の水は下流の水田群へ流れる. また溜池Wに 関しては上流部W-1と下流部W-2に分けて採水している．

更に鉄濃度の高い東の谷と比較するため, 鉄濃度が 高いと考えられる沢水か浾褐色である逆樣池周辺の炭所 西地区の沢A，B，Cを選定し調査を行った .これらの沢 水は籣蒼とした林内を通り，道路脇の側溝に流れており， 人為的影響が少ない地点である。

現地調査では, ポータブル計器により水深, $\mathrm{pH}, \mathrm{EC}$, ORP , DOを測定した .また , 各調査ポイントにつき現 地で150ml採水し, 土壤サンプル, 観測地点での優先種 である植物サンプルも採取した . 持ち帰った水サンプル は, 分析するまで邻暗所にて保存した . また , 水サンプ ルを $1 \%$ 硝酸て鉄を溶出させた後, $0.45 \mu$ mフィルターに よりろ過し，ICP発光分光分析により鉄濃度を測定した． ICP発光分光分析装置の鉄の検出限界は $0.0003 \mathrm{mg} / \mathrm{L}$ であ

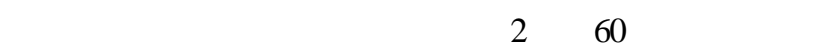

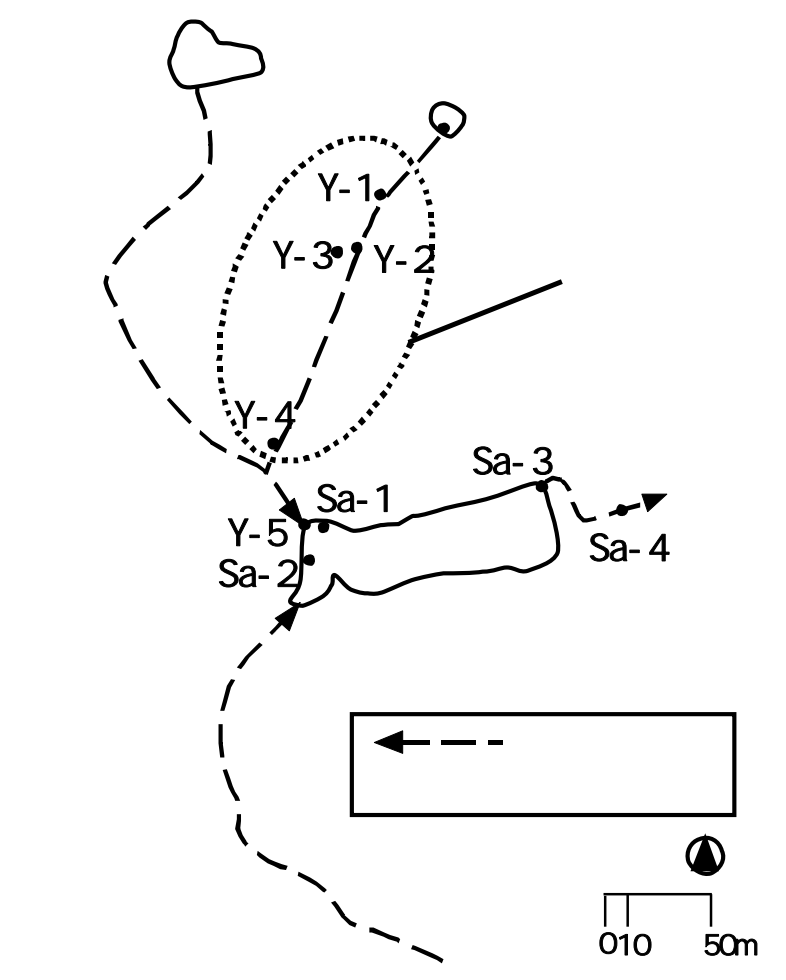

図-2 逆樣池流域の調査地点

乾燥させた後, 植物サンプル約 $0.1 \mathrm{~g} に$ 対して $2 \%$ の硝酸 $50 \mathrm{ml}$ 加えた . 弚の溶液の鉄濃度をICP発光分光分析で 測定した . また土壤, 岩石サンプルを $100^{\circ} \mathrm{C} て ゙ 十$ 分に炉 乾燥させた後, サンプル0.01gに対して $5 \%$ の塩酸 $100 \mathrm{~mL}$ を加えた . 兴の溶液の鉄濃度をICP発光分光分析で測定 した .

\section{3.結果と考察}

図-3に2004年から2005年の逆樣池流域及び溜池P , Q , $\mathrm{V}, \mathrm{W}$ における鉄濃度の流下方向の变化を示す . 夏期の 鉄濃度の傾向として , 最上流部の小池で $1 \mathrm{mg} /$ L以上あり， 鉄濃度か高くなっており, 東の谷のY-1地点て増加し , 光の後流下するにつれて減少し, 逆樣池内では鉄濃度は 高い傾向である . Y-1地点, 逆樣池内のSa-1の鉄濃度は 常に2mg/L以上の高い値を示している. 特にこれらの地 点の水は赤褐色であり，腐植土の堆積が見られた .

溜池P，Qの水の色は焦げ茶色である. 溜池PからQの 鉄濃度は低い傾向を示す．このことから，隣接の溜池で あるP，Qの焦げ茶色を呈する水は鉄濃度が低いことが わかる.

溜池V，Wの鉄濃度はVからWにかけて $1 \mathrm{mg} / \mathrm{L}$ 以上であ り, 溜池Wの下流部て増加する .この溜池の水は逆樣池 と同樣に赤褐色を示す .このことから , 赤褐色の溜池の 箇所では鉄濃度が高いことか推測される。

また図-4に炭所西地区の沢A，B，Cにおける流下過程 における鉄濃度の变化を示す . 沢Aの上流部では鉄濃度 

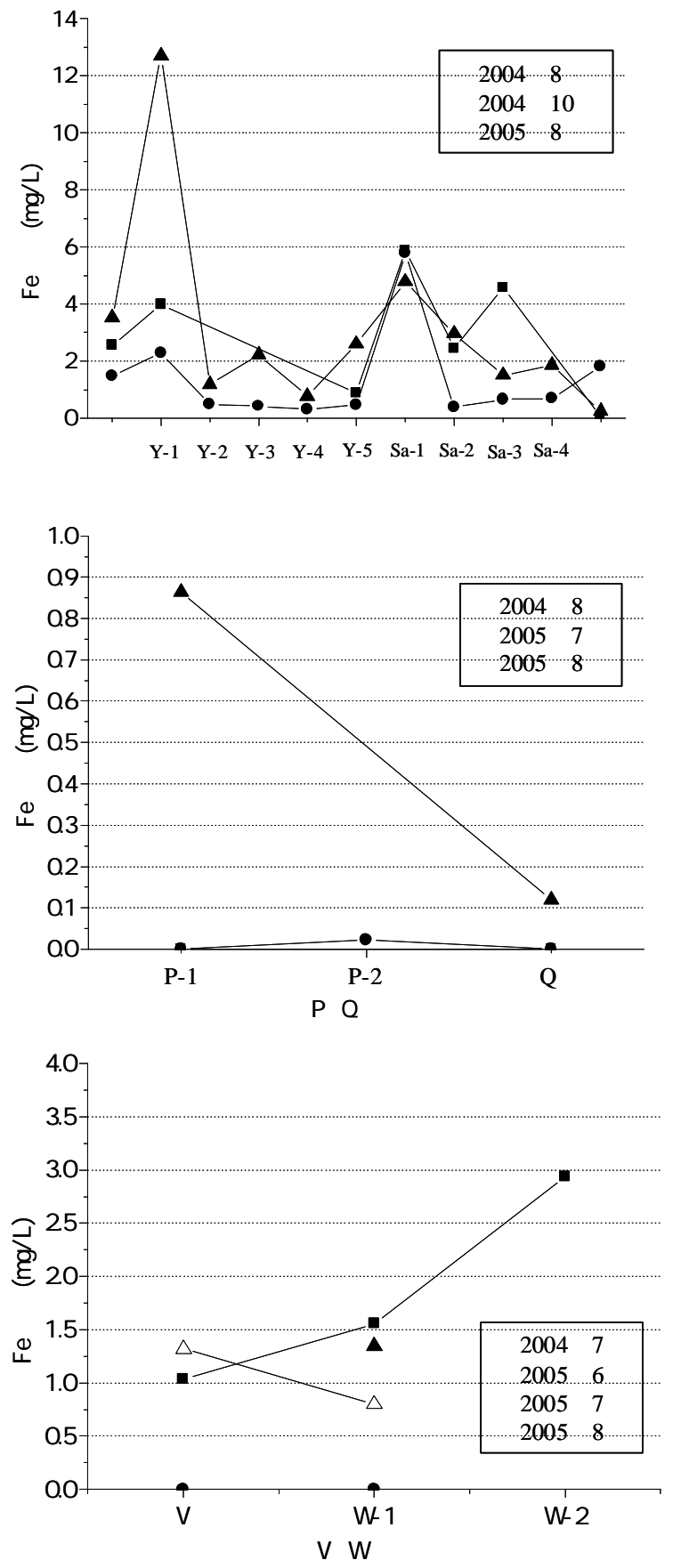

図-32004年～2005年の逆樣池流域

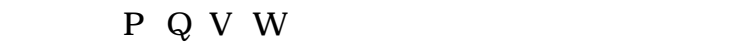

が40mg/L以上と非常に高いが，下流部では2004年7月を 除き，低い值を示した .この原因として，2004年7月で は水の流れがなく停带しており，光れ以外の調査日では 水が流れていたことか学げられる . 沢B-1〜沢B-3までは 鬱蒼とした暗い林内であり，B-4とB-5に分かれ，弚の後 合流し，沢B-6に流れる．2005年6月の調査以降沢B-5は 干上がった . 沢B-5では沢Bの他の地点に比へて落葉落 枝が多く堆積しており，鉄濃度は $1309.1 \mathrm{mg} / \mathrm{L}$ 非常に高 かった .
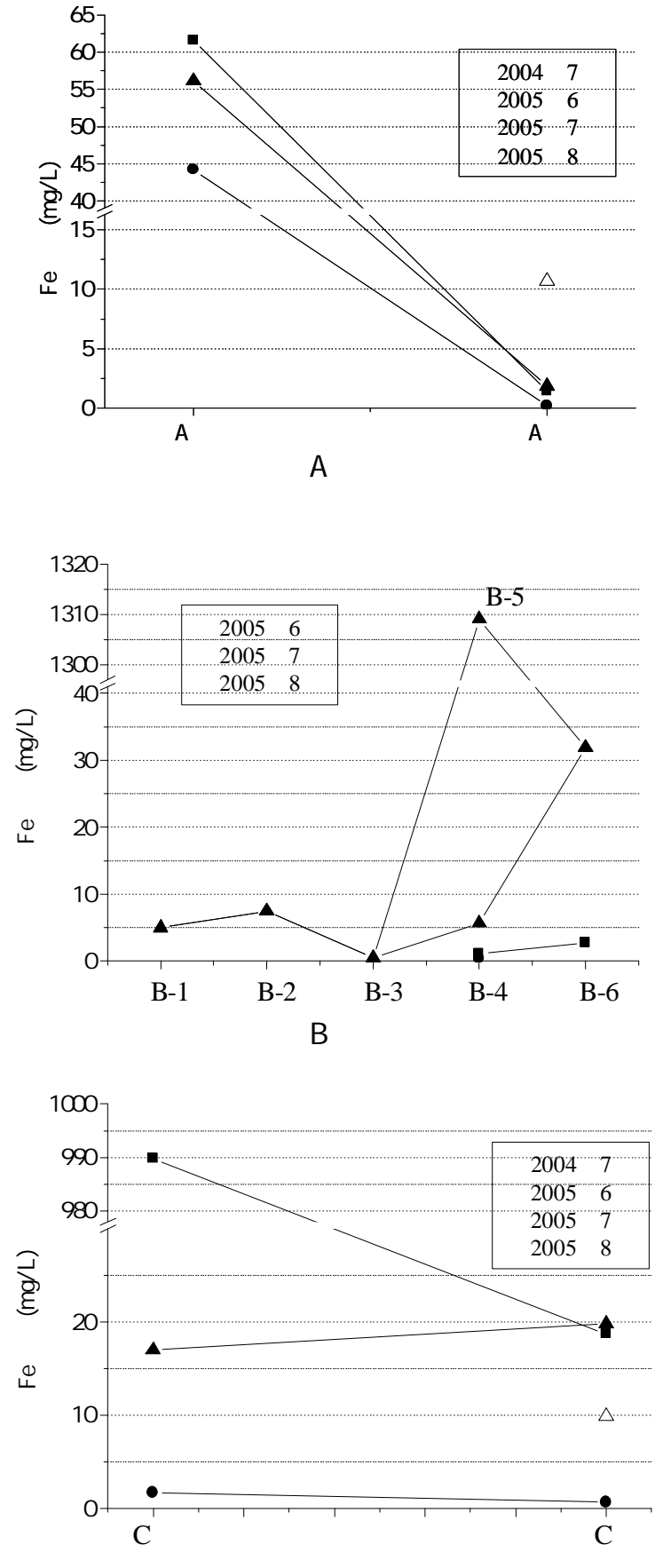

沢C 調査地点

図-42004月7月，2005年6, 7,8月の炭所西地区の 沢 $A$, 沢B , 沢 $Q$ こおける流下過程での鉄の濃度变化

沢Cの上流部において調査日により鉄濃度は大きく異 なる . 2005年8月において , 鉄濃度は $989.8 \mathrm{mg} / \mathrm{L}$ 非常に 高かった . 鉄濃度は常に $1 \mathrm{mg} / \mathrm{L}$ 以上あり，他の流域に比 べて高いといえる．沢Cの特徵として，上流部ではスギ が多い. 最上流部てはモウソウチク林であり湿っており， 水源であると考えられるが，湧水量が少なく採水できな かった . 沢Cの下流は赤褐色の水が流れていた . 下流で も鉄濃度は調査日により大きく異なっている。

図-5に2005年7月の東の谷及び逆樣池, 溜池V, W , 沢 $\mathrm{A}$ 上流, 沢C上流の調査において優先していた植物体 
の乾燥重量 $1 \mathrm{~g}$ 当たりの鉄含有量を示す．また表-1に，鉄 か検出されなかった植物の一覧表を示す．逆樣池流域で は, 東の谷に生えていたネジキ , ヤマザクラ , スギ , シ 冬p. , オンツツツジなどの陸生植物からは鉄か検出されな かった 、しかし逆樣池に生えていたジュンサイ , カンガ レイ , ヤマイなどの水生植物からは $0.6 \mathrm{mg} / \mathrm{g}$ 以上の鉄が 検出された .

溜池Vではジュンサイ , タヌキモ , ヒルムシロなどの 水生植物から $0.09 \sim 0.5 \mathrm{mg} / \mathrm{g}$ の鉄力柣出された .ここで, 逆樣池のジュンサイから検出された鉄は $2.6 \mathrm{mg} / \mathrm{g}$ と高く， 溜池Vのジュンサイから検出された鉄は $0.2 \mathrm{mg} / \mathrm{g}$ と低い . このことから同じジュンサイでも生育する環境条件によ り鉄含有量に大幅な違いがあると考えられる . 溜池Wで は池内に葉を落としているヤマハゼ , コウゾ, コナラな どの陸生植物からは鉄は検出されなかった . しかしガマ , クロモなどの水生植物からは $1.3 \sim 3.9 \mathrm{mg} / \mathrm{g}$ という高い鉄 か検出された . 尚, 溜池Wについては他にジュンサイ , ヒシを確認したが, 溜池中央部に生えており採取か困難 であった . 沢A上流ではナツフジ , ササsp. , ヤマハゼ , ヤブツバキなどの陸生植物を分析したが，いずれも鉄は 検出されなかった .

沢C上流ではカンボク , シダsp. , ヒメウツギ , 二ガキ， コツクバネウツギ , カナメモチ , スギ , モウソウチク , スギ (枯れ枝) などの陸生植物からは鉄が検出されな かったが，モウソウチク (枯れ枝) からは $0.2 \mathrm{mg} / \mathrm{g}$ の鉄 か検出された .

これらのことから水生植物は水の鉄濃度の影響を受け やいと考えられる . また陸生植物はモウソウチクを除く と，鉄は検出されず，池内への鉄の供給源として陸生の 植物は考えられない。

表-2に，2005年10月の沢A上流の沢土壤，沢C上流の 赤色泥 , 及ひ新鮮な岩石の1gあたりに含まれる鉄含有量 を示す . 土壤 , 岩石の各サンプルは3サンプルでの平均 値を示す .ここで沢Cの赤色泥とは, 植物の落葉落枝が 堆積して生成された腐植質と考えられる赤い泥を表すこ ととする．また，沢Aの土猿は主に砂利，砂，粘土て構 成される .これらは花崗岩の風化物である . また, 新鮮 な岩石は花崗岩である . 沢A上流では岩石に含まれる鉄 は1gあたり72mg，沢C上流では208mgを示した .一方， 新鮮な岩石の鉄含有量は28mgと沢A,Cの土壌よりも低い，

したがって, 新鮮な岩石からは鉄は溶出しにくく, 赤 色泥から鉄が容出しやすいことかわかった .

これらの結果から，沢C上流の陸生植物の鉄含有量は 低いが, 光れら陸生植物の落葉落枝か水中に堆積して生 成した沢C上流の赤色泥には鉄が含まれていた .このこ とから，陸生植物は生育している状態だけでは鉄を蓄え ないが, 腐植質の泥には鉄力蓄積されると考えられる。 一般に, 污濁河川や泥炭地ては, 溶存鉄がフミン酸やフ ルボ酸といった有機物とコロイドを作る ${ }^{3)}$. 香川県では 降雨量が少なく, 晴天か続くとこれらの沢では流量が少

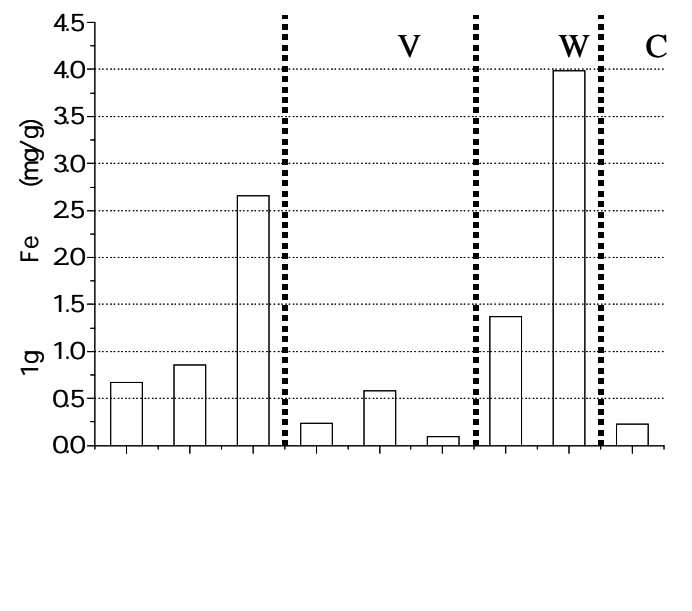

图- 5 2005年7月の各調査において優先していた 植物体の乾燥重量1g当たりの鉄濃度

表-1 鉄か鉿出されなかった植物の一覧表

\begin{tabular}{|c|c|c|c|}
\hline 調査地点 & サンプル名 & 調査地点 & サンプル名 \\
\hline \multirow{5}{*}{ 東の谷 } & ネジキ & \multirow[t]{3}{*}{ W- 2} & ヤマハゼ \\
\hline & ヤマザクラ & & コウゾ \\
\hline & スギsp. & & コナラ \\
\hline & シダsp. & \multirow[t]{7}{*}{ 沢C上流 } & カンボク \\
\hline & オンツツツジ & & シダsp. \\
\hline \multirow[t]{5}{*}{ 沢A上流 } & ナツフジ & & ヒメウツギ \\
\hline & ササsp. & & ニガキ \\
\hline & ヤマハゼ & & コソクバネウツギ \\
\hline & ヤブツバキ & & カナメモチ \\
\hline & & & スギsp. 枯れ枝) \\
\hline
\end{tabular}

表- 2 2005年10月の各調査地点における底泥及び赤色 泥1gあたりに鉄含有量

\begin{tabular}{|c|c|}
\hline サンプル & $\mathrm{Fe}(\mathrm{mg} / \mathrm{g})$ \\
\hline 沢A上流 沢土壤 & 72.0 \\
\hline 沢C上流 赤色泥 & 208.5 \\
\hline 新鮮な岩石(3) & 28.1 \\
\hline
\end{tabular}

なく水が停滞するため，泥炭地に似た環境か形成される． その時に腐植質が容存鉄を蓄えると考えられる。

図-6に，2004年10月，2005年6，7，8月の調査におけ

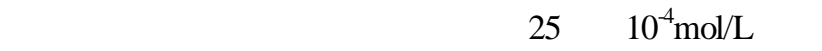
ける鉄形態別の電位-pH図を示す . 図-6(a) では溜池P , $\mathrm{Q}, \mathrm{V}, \mathrm{W}$ において酸化還元電位力非常に高く, 鉄は3価 の状態で安定しており, 鉄は固体の状態で沈殿する .溜 池P，Qでは鉄濃度は低く鉄は溶けにくい，溜池V，Wで は溜池P，Qよりも若干酸化還元電位力゙低く，2価の鉄イ オンの領域に近い，逆樣池流域は溜池P , Q , V , Wに比 べて全体的に酸化還元電位が低く，より2価の鉄イオン が溶出しやすいといえる .

図-6(b)の沢の図では沢Bにおいて酸化還元電位が高 く, 鉄は3価て安定しているといえる . 沢Bでは , 沢B-5 を例外として乥れほど腐植土か堆積していなかったので， 
酸化還元電位か高かったと考えられる . 沢Aは酸化還元 電位が低く，全体が0.4V以下であり，2価と3価の鉄の安 定領域の境界に沿っている.つまり沢Aではわずかに酸 化還元電位が低下する，もしくは沢水のpH力酸性にな ると，容易に2価の鉄が容出しやすい環境である．沢C は沢A，Bに比べてpHが低いので2価の鉄の領域に近い . 2005年8月の沢C上流地点では, 2 価の鉄か安定する環境 であった . このときの鉄濃度は $989.8 \mathrm{mg} / \mathrm{L}$ と非常に高く， 鉄か2価の鉄として溶け出ていると考えられる . 沢A，C は上流, 下流とも腐植土が多く堆積していたので, 酸化 還元電位が低かったと考えられる . 図- $6(\mathrm{c})$ の底泥及び 赤色泥の図の調査地点は , 表2で示した底泥及び赤色泥 を採取した地点と同一の地点である. 逆樣池や沢A上流 の環境下ではpHが高いために，鉄は3価として安定して いる．Y-1，沢B-4，沢C上流では2価の鉄の安定領域に 近いことから, 少しの環境の変化で2価の鉄イオンが容 け出ると考えられる . 2価の鉄の安定領域に入っている のは，2005年8月における沢C上流のサンプルである . このときの沢C上流では，2価の鉄イオンが容出してい ると考えられる .

逆樣池及び炭所西地区は領家花崗岩力゙分布する.この 地域の花崗岩はマサ化か著しく，場所によると山全体が マサ状になっているところがある゙. 花崗岩の主成分は 石英, カリウム長石, ナトリウム斜長石, 黑雲母, 乥し て微量の角閃石であり，これらはすべてケイ酸塩鉱物で

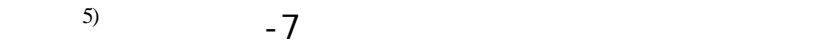
対する造岩鉱物の抵抗性を示す .一般にケイ酸イオンの 構造が複杂倠になるにつれて風化に対しての抵抗性は増す 5). また，代表的な火成岩の平均化学組成を表-3に示す 5).花崗岩は $\mathrm{Fe}_{2} \mathrm{O}_{3}$ を $1.57 \% ， \mathrm{FeO} 1.78 \%$ 含んでいる. 一 般に, 石英閃緑岩が風化を受けたときの化学組成変化と して， $\mathrm{FeO}$ 著しく減少し， $\mathrm{Fe}_{2} \mathrm{O}_{3}$ を含む残留物力残るこ とか知られている5)。また図８に，風化した岩石から2価 の鉄イオンが容出するモデルを示す . 新鮮な岩石では , 鉄はケイ酸塩鉱物中に含まれているので, 酸性環境下で もなかなか溶けないが, 岩石か渢化されてケイ酸塩の結 晶構造から外れた $\mathrm{Fe}_{2} \mathrm{O}_{3}$ の状態ならは酸性環境下で比較 的容易に鉄は溶けると考えられる。

逆樣池流域及び炭所西地区の沢のpHは，赤色泥を採 取したY-1で6.26，沢A下流で6.73の弱酸性であった . ま た，逆樣池，沢A上流，沢B-5，沢C上流，沢C下流いず れの流域も多量の腐植土があり，酸化還元電位は $0.4 \mathrm{VW}$ 下と低く, $\mathrm{pH}$ は弱酸性である.こうした環境下で花崗 岩が風化した $\mathrm{Fe}_{2} \mathrm{O}_{3}$ が供給されると, 水中に2価の鉄イオ ンとしていくらか溶けると考えられる．つまり腐植土の 分解による酸化還元電位の低下と, 腐植土から供給され る腐植酸によるpHの低下が, 風化した花崗岩から供給 される $\mathrm{Fe}_{2} \mathrm{O}_{3}$ を溶かし，この流域一帯に高濃度の鉄を供 給していると考えられる .

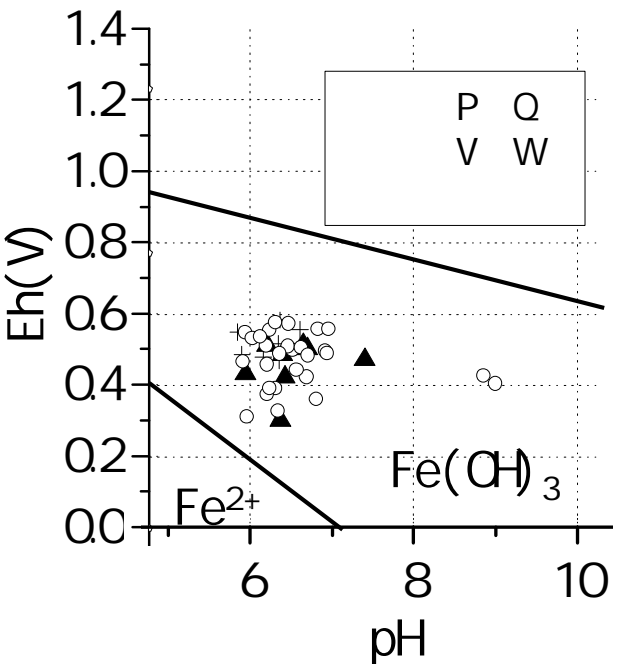

(a) 溜池

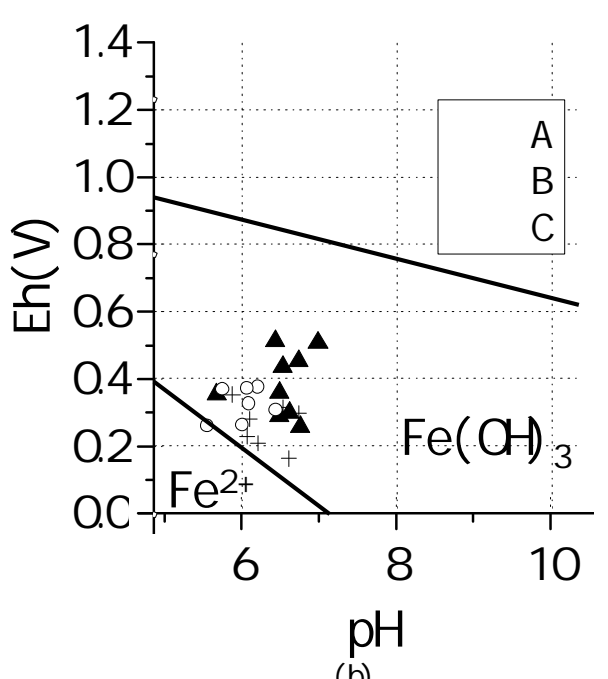

(b) 沢

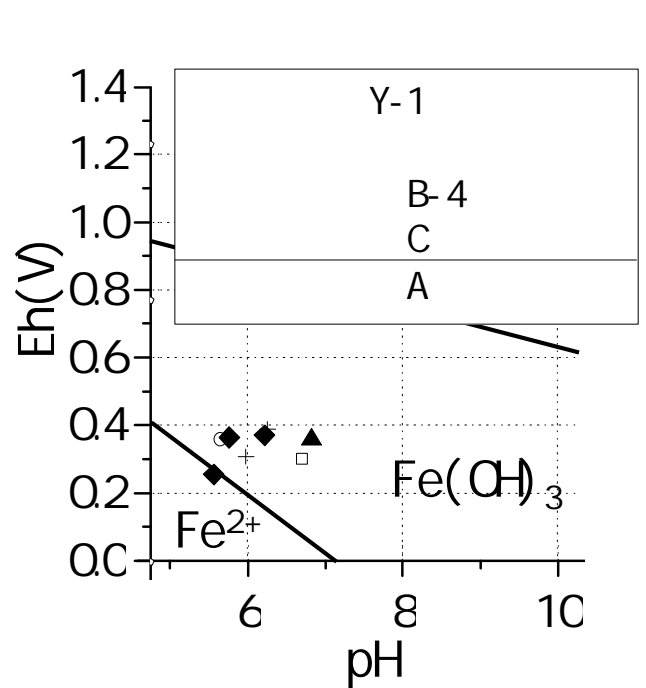

(c) 底泥及ひ浾色泥

図-62004年10月，2005年6，7，8月の調査における溜 池及び沢水，底泥及び赤色泥の鉄形態別の電位- $\mathrm{pH}$ $\left(25^{\circ} \mathrm{C}, 1 \mathrm{C}^{4} \mathrm{nol} / \mathrm{L}\right)$ 


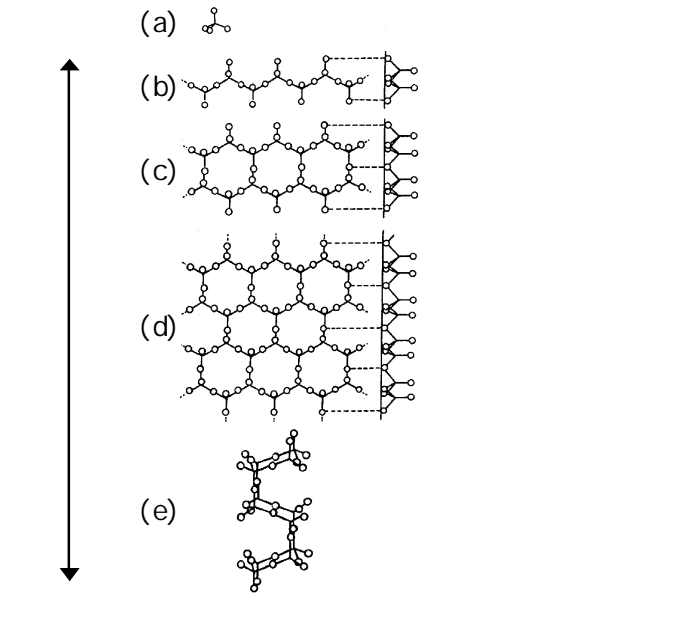

图 7 ケイ酸塩鉱物の骨格構造と風化に対する造岩鉱物

\section{4.まとめ}

本研究は, 還元状態にある貧栄養池においての鉄の起 源について考察した . 弚こで, 香川県の貧栄養池である 逆樣池流域と光の周辺の溜池及び沢水の水，土，植物の 鉄濃度を解析した，光の結果, 逆樣池流域及ひ炭所西地 区の溜池と周辺の沢水の鉄濃度は非常に高く，特に沢水 では $50 \mathrm{mg} / \mathrm{L}$ に達している . 弚れらの地点の特徵として は，水か浾褐色である. 弚こで水，土，岩石，及ひ植物 の鉄濃度を比較することにより鉄の起源を考察した . 逆 樣池流域と周辺の沢水の鉄濃度は上流で高く，下流で咸 少した。特に, 非常に高い鉄濃度は, 森林て囲まれた湿 地の中て観測された。腐植土等の有機物が分解しにくい 還元的な環境は，鉄の溶解度を高めると考えられる. 光 のため還元的な環境下 (水中) では鉄の溶解度が高いた め, 乥こて生育する水生植物の鉄濃度は高かった．乥れ に対して, 森林の周りの酸化的な環境下 (陸上)では鉄 の溶解度は低いため, 弚こで生育する陸生植物の鉄濃度 は非常に低かった。またEh-pH图から酸性，還元的条件 では新鮮な岩石の成分である $\mathrm{FeSiO}_{3}, \mathrm{Fe}_{2} \mathrm{SiO}_{2}$ 等からは， 鉄は容易に溶解しないが, 岩石が風化して形成される

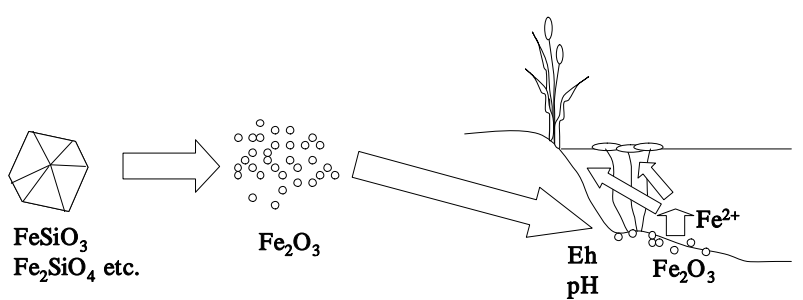

図-8 風化した岩石からの鉄（II）イオン溶出のモデル

表3 代表的な火成岩の平均化学組成

\begin{tabular}{l|rrr|rrr}
\hline & 玄武岩安山岩 流紋岩 & ガブロ & 閃緑岩 & 花崗岩 \\
\hline $\mathrm{SiO}_{2}$ & 49.06 & 59.59 & 72.80 & 48.24 & 58.90 & 70.18 \\
$\mathrm{Al}_{2} \mathrm{O}_{3}$ & 15.70 & 17.31 & 13.49 & 17.88 & 16.47 & 14.47 \\
$\mathrm{Fe}_{2} \mathrm{O}_{3}$ & 5.38 & 3.33 & 1.45 & 3.16 & 2.89 & 1.57 \\
$\mathrm{FeO}$ & 6.37 & 3.13 & 0.88 & 5.95 & 4.04 & 1.78 \\
$\mathrm{H}_{2} \mathrm{O}$ & 1.62 & 1.26 & 1.47 & 1.45 & 1.27 & 0.84 \\
\hline
\end{tabular}

$\mathrm{Fe}_{2} \mathrm{O}_{3}$ の状態なら溶解しやすい, 逆樣池流域, 炭所西地 区の溜池及び沢の底泥は, 鉄は花崗岩が風化した $\mathrm{Fe}_{2} \mathrm{O}_{3}$ の状態であると考えられ，腐植土からの腐植酸の供給に よる水質の酸性化, 腐植土が作り出す還元的環境て鉄が 容易に溶け出したと考えられる。

\section{参考文献}

1) 室賀英治, 井伊博行 , 中島敦司 : 酸素欠乏環境下ての有機 物分解に伴う貧栄養化現象, 土木学会, 環境工学研究論文 集, Vol.41，pp701-707，2004.

2) A.J.ホーン, C.R ゴールドマン: 陸水学, 京都大学学術出 版会, p23-24, pp197-199, pp201-204, 1999 .

3） 日本環境管理学会編 : 新水道水質基準ガイドブック 建築 物の水環境管理，丸善株式会社，pp95-96, 1994 .

4) 国土交通省国土調査課，1/50000土地分類基本調査（地形 分類图)「池田」, 香川県, 德島県, 1972 .

5）多賀光彦，那須淑子 : 地球の化学と環境 第2版，三共出 版株式会社, p27, pp33-34, p44,pp53-55，2001.

6) 周藤賢治, 小山内康人 : 記載岩石学 岩石学のための情報 収集マニュアル, 共立出版, 2003.5

(2005. 9. 30受付) 